\title{
METODE MAKE A MATCH DALAM PEMBELAJARAN AQIDAH AKHLAK DI MADRASAH IBTIDAIYAH
}

\author{
Titin Suprihatin \\ Fakultas Tarbiyah dan Keguruan, UIN Sunan Gunung Djati, Bandung, Indonesia \\ si.titinsuprihatin@gmail.com
}

Naskah diterima: 25 Desember, 2017, direvisi: 1 januari, 2018, diterbitkan: 31 Maret, 2018

\begin{abstract}
The purpose of this study is to analyze student learning outcomes before using the method of learning make a match, describe the implementation of learning process Akidah Akhlak material behave commendable using the method of learning make a match, and describe student learning outcomes after using the method of learning make a match on the subjects Akidah Akhlak the material behaves commendable in the fourth class of MIS Cikulu. Make a match is an active learning method to deepen or train the learned material. Students are asked to look for pairs of cards which are answers or specific material questions in the lesson. One of the advantages of this technique is students looking for a partner while learning about a concept or topic in a fun atmosphere. This research uses Classroom Action Research method. Respondents in this study as many as 15 students of class IV MIS Cikulu Sukahurip Village, Pangandaran District, Pangandaran City. Based on the results of data analysis from the evaluation of students on subjects Akidah Akhlak material behave commendably by using the method of learning make a match obtained student learning outcomes in cycle I with an average value of 68.67 and on cycle II with an average value of 88 . Thus there is a significant increase in the learning process by using the method of learning make a match on the subject Akidah Akhah material behave commendably between cycles I and II.
\end{abstract}

Keywords: student learning, make a match, akidah akhlak, madrasah ibtidayah

\begin{abstract}
ABSTRAK
Tujuan penelitian ini adalah menganalisis hasil belajar siswa sebelum menggunakan metode pembelajaran make a match, mendeskripsikan keterlaksanaan proses pembelajaran Akidah Akhlak materi berperilaku terpuji dengan menggunakan metode pembelajaran make a match, dan mendeskripsikan hasil belajar siswa setelah menggunakan metode pembelajaran make a match pada mata pelajaran akidah akhlak materi berperilaku terpuji di kelas IV MIS Cikulu. Make a match merupakan metode pembelajaran aktif untuk mendalami atau melatih materi yang dipelajari. Siswa diminta mencari pasangan kartu yang merupakan jawaban atau pertanyaan materi tertentu dalam pembelajaran. Salah satu keunggulan teknik ini adalah siswa mencari pasangan sambil belajar mengenai suatu konsep atau topik dalam suasana yang menyenangkan. Metode penelitian yang digunakan dalam penelitian ini adalah metode Penelitian Tindakan Kelas (PTK). Responden dalam penelitian ini sebanyak 15 siswa kelas IV MIS Cikulu Desa Sukahurip Kecamatan Pangandaran Kota Pangandaran. Berdasarkan hasil analisis data dari evaluasi siswa pada mata pelajaran Akidah Akhlak materi berperilaku terpuji dengan menggunakan metode pembelajaran make a match diperoleh hasil belajar siswa pada siklus I dengan nilai rata-rata 68,67 dan pada siklus II dengan nilai rata-rata 88 . Dengan demikian ada peningkatan yang signifikan pada proses pembelajaran dengan menggunakan metode pembelajaran make a match pada mata pelajaran Akidah Akhlak materi berperilaku terpuji antara siklus I dan II.
\end{abstract}

Kata Kunci : hasil belajar siswa, make a match, akidah akhlak, madrasah ibtidaiyah 


\section{PENDAHULUAN}

Pendidikan merupakan usaha sadar dan terencana untuk mewujudkan suasana belajar dan proses pembelajaran sehingga peserta didik secara aktif mengembangkan potensi dirinya untuk memiliki kekuatan spiritual keagamaan, pengendalian diri, kepribadian, kecerdasan, akhlak mulia, serta keterampilan yang diperlukan, masyarakat, bangsa, dan negara (Undang-undang RI No. 20 tahun 2003). Sedangkan menurut Dewantara (Pidarta, 2007, hlm. 10) yang mengatakan bahwa pendidikan adalah menuntun segala kekuatan kodrat yang ada pada anak-anak, agar mereka sebagai manusia dan sebagai anggota masyarakat mendapat keselamatan dan kebahagiaan yang setinggi-tingginya. Pendidikan bertujuan untuk mengembangkan individu baik jasmani maupun rohani secara optimal, agar mampu meningkatkan hidup dan kehidupan diri, keluarga, dan masyarakat (Pidarta, 2007, hlm. 9).

Untuk mewujudkan usaha tersebut, khususnya pada mata pelajaran akidah akhlak, guru berkewajiban untuk merubah proses pembelajaran akidah akhlak menjadi lebih menyenangkan, pembelajaran akidah akhlak di MI mempunyai kedudukan yang sangat penting dalam upaya untuk mencapai tujuan pendidikan yang telah ditetapkan. Guru diharapkan dapat merancang dan mengelola proses pembelajaran, agar dapat mengajarkan akidah akhlak dengan baik dan dapat meningkatkan hasil belajar siswa.

Hasil belajar adalah pola-pola perbuatan, nilai-nilai, pengertian-pengertian, sikap-sikap, apresiasi dan keterampilan. Yang harus diingat, hasil belajar adalah perubahan prilaku secara keseluruhan bukan hanya satu aspek potensi kemanusiaan saja. Artinya, hasil pembelajaran yang dikategorisasi oleh para pakar pendidikan sebagaimana tersebut di atas tidak dilihat secara fragmentaris atau terpisah, melainkan komprehensif (Suprijono, 2014, hlm. 7).

Akidah akhlak merupakan salah satu mata pelajaran Kegamaan yang mempelajarai tentang prilaku terpuji serta menciptakan suasana keteladanan dan pembiasaan dalam mengamalkan akhlak terpuji dan adab Islami melalui pemberian contoh-contoh prilaku dan cara mengamalkannya dalam kehidupan sehari-hari. Salah satu mata pelajaran yang tercakup dalam struktur kurikulum Madrasah Ibtidaiyah (MI) adalah pelajaran Akidah Akhlak. Secara institusional, tujuan pembelajaran Akidah Akhlak di MI diformulasikan dalam bentuk Standar Kompetensi Lulusan (SKL), salah satunya yaitu menghafal, memahami arti, dan mengamalkan akhlak terpuji pilihan tentang akhlak dan amal saleh.

Berdasarkan observasi yang telah dilakukan oleh penulis di kelas IV MIS Cikulu Desa Sukahurip Kecamatan Pangandaran Kota Pangandaran, penulis melihat bahwa pembelajaran di kelas berlangsung monoton dan terpusat pada guru. Dimulai dari guru menulis materi di papan tulis, kemudian murid mencatatnya setelah itu guru menerangkannya. Jadi, peserta didik hanya duduk, diam, dengar, catat dan hafal (3DCH). Ini berdampak pada hasil belajar kognitif mereka, yaitu hampir 50\% siswa kelas IV MIS Cikulu mempunyai nilai di bawah KKM yaitu 70. Maka dari itu perlu adanya perubahan paradigma dalam proses belajar siswa dan interaksi antara siswa dan guru. Sudah sebaiknya kegiatan belajar mengajar lebih mempertimbangkan siswa. Siswa bukanlah sebuah botol yang bisa diisi dengan muatan-muatan informasi apa saja yang dianggap perlu oleh guru. Selain itu, alur proses belajar tidak harus berasal dari guru menuju siswa. Siswa juga bisa saling mengajar dengan sesama siswa lainnya.

Tuntutan dalam dunia pendidikan sudah banyak berubah. Kita tidak bisa lagi mempertahankan paradigma lama tersebut. Guru harus berani mengubah paradigma pengajaran yang seperti itu. Pendidik perlu menyusun dan melaksanakan kegiatan belajar mengajar yang inovatif dan variatif. Salah satunya yaitu dengan mengubah metode pembelajaran.

Menurut Abdorrakhman (Heriawan, dkk 2012:74 ) metode pembelajaran adalah cara atau pola yang khas dalam memanfaatkan berbagai prinsip dasar pendidikan serta berbagai teknik dan sumber daya terkait lainnya agar terjadi proses pembelajaran pada diri pembelajar. Metode merupakan jabaran dari pendekatan. Satu pendekatan dapat dijabarkan kedalam berbagai metode. Metode adalah prosedur pembelajaran yang difokuskan ke pencapaian tujuan.

Metode pembelajaran make a match merupakan metode pembelajaran yang dikembangkan Loma Curran, ciri utama metode make a match adalah siswa diminta mencari pasangan dimana siswa mencari pasangan sambil belajar mengenai suatu konsep atau topik dalam suasana yang 
menyenangkan. Jumlah siswa dalam satu kelompok tidak boleh terlalu besar, yang terdiri dari 2 orang atau lebih. Hal ini dimaksud agar proses kerjasama antar siswa berjalan efektif, sehingga memungkinkan semua siswa terlibat secara aktif dalam pembelajaran untuk membahas dan memecahkan masalah. Sehingga diharapkan dengan penggunaan metode make a match dapat meningkatkan hasil belajar siswa terutama dalam mata pelajaran akidah akhlak (Shoimin, 2014, hlm. 98).

Berdasarkan paparan teori di atas, dalam melakukan proses belajar-mengajar guru tidak lagi mendominasi seperti lazimnya pada saat ini, sehingga siswa dituntut untuk berbagi informasi dengan siswa yang lainnya dan saling belajar mengajar sesama mereka. Dengan begitu, keberhasilan belajar akan lebih meningkat karena sebagian besar peserta didik terlibat aktif dalam proses pembelajaran, dan dalam sistem ini guru bertindak sebagai fasilitator.

Metode pembelajaran Make A Match merupakan metode yang dapat memberikan siswa memiliki pengalaman baru dalam belajar dan diharapkan akan menjadikan proses pembelajaran lebih bervariatif, sehingga menjadikan siswa tidak merasa jenuh dengan pembelajaran tersebut dan diharapkan hasil belajar kognitif siswa dalam mata pelajaran Akidah Akhlak menjadi lebih meningkat.

\section{METODOLOGI}

Metode penelitan adalah tahapan-tahapan cara dalam melaksanakan penelitian (Aqib, 2009, hlm. 33). Metode penelitian yang digunakan dalam penelitian ini adalah metode penelitian tindakan kelas (classroom action research). PTK pertama kali diperkenalkan oleh psikologi sosial Amerika yang bernama Kurt Lewin pada tahun 1946. Inti gagasan Lewin inilah yang selanjutnya dikembangkan ahli-ahli lain seperti Stephen Kemmis, Robin Mc. Taggart, John Elliot, Dave Ebbutt dan sebagainya. Di Indonesia sendiri PTK baru dikenalkan pada akhir dekade 80-an.

Menurut Aqib (2009, hlm. 19) Penelitian Tindakan Kelas (PTK) adalah penelitian yang dilakukan oleh guru di kelas atau di sekolah tempat ia mengajar dengan penekanan pada penyempurnaan atau peningkatan proses dan praktik pembelajaran. PTK memiliki tujuan yaitu untuk memperbaiki dan meningkatkan kualitas praktik pembelajaran secara berkesinambungan, sehingga meningkatkan mutu hasil instruksional; mengembangkan keterampilan guru; meningkatkan relevansi; meningkatkan efisiensi pengelolaan instruksioanal serta menumbuhkan budaya meneliti pada komunitas guru.

Menurut Aqib, (2009, hlm. 31) langkah-langkah dalam PTK merupakan satu daur atau siklus yang terdiri dari:

1. Merencanakan perbaikan;

2. Melaksanakan tindakan;

3. Mengamati; dan

4. Melakukan refleksi

Subjek penelitian ini adalah siswa kelas IV MIS Cikulu Desa Sukahurip Kecamatan Pangandaran Kota Pangandaran yang berjumlah 15 orang dengan alasan rata-rata hasil belajar siswa di kelas tersebut masih dibawah KKM. Sedangkan objek penelitian ini adalah hasil belajar siswa kelas IV MIS Cikulu Desa Sukahurip Kecamatan Pangandaran Kota Pangandaran.

Penelitian ini mengambil lokasi di MIS Cikulu Desa Sukahurip Kecamatan Pangandaran Kota Pangandaran. Adapun alasan penulis memilih lokasi tersebut karena terdapat permasalahan yang mendukung untuk dilakukannya penelitian ini.

Penelitian tindakan kelas ini direncanakan dalam tiga siklus. Tiap siklus terdiri dari empat tahap yaitu perencanaan, tindakan, observasi, dan refleksi.

Kegiatan yang dilakukan dalam perencanaan antara lain sebagai berikut. 
1. Menyusun rencana pembelajaran tentang standar kompetensi, dan setiap pertemuan satu rencana pelaksanaan pembelajaran.

2. Mempersiapkan media metode pembelajaran Make A Match yang terkait dengan materi berperilaku terpuji.

3. Menyusun instrument penelitian berupa lembar observasi aktivitas guru dan siswa.

4. Menyediakan lembar penilaian tes unjuk kerja.

Kegiatan yang dilakukan dalam tahap tindakan adalah memberikan gambaran tentang proses pembelajaran yang akan dilakukan dengan melakukan tujuan pembelajaran yang ingin dicapai. Setelah itu siswa dibagi menjadi tiga kelompok yaitu kelompok pertanyaan, kelompok jawaban, dan kelompok penilai dengan cara siswa berhitung dari 13 dan kembali lagi ke satu sampai seluruh siswa mendapatkan kelompoknya, siswa dibagi menjadi tiga kelompok yaitu kelompok pertanyaan, kelompok jawaban, dan kelompok penilai dengan cara siswa berhitung dari 1-3 dan kembali lagi ke satu sampai seluruh siswa mendapatkan kelompoknya, siswa berkumpul menurut kelompoknya masing-masing, menerima bahan ajar tentang indahnya berperilaku terpuji, menerima kartu-kartu pertanyaan kepada kelompok (pertanyaan) dan kartu jawaban kepada kelompok siswa (jawaban) yang tidak boleh dibuka sebelum ada perintah dari guru dan kelompok penilai menunggu sampai semua kartu pertanyaan dan jawaban diserahkan, ketika guru memberikan aba-aba masing-masing anggota kelompok mencari pasangan (pertanyaan dan jawaban), siswa berhenti ketika aba-aba kedua, dan siswa mendatangi kelompok penilai (mencocokkan pertanyaan dan jawaban), kelompok penilai memberikan penilaian apakah kartu-kartu pasangan itu cocok atau tidak, untuk siswa yang dapat mencocokkannya diberi nilai 2 dan yang tidak diberi nilai 1, kelompok penilai menjelaskan hasil penilaian mereka terhadap pasangan kartu (pertanyaan dan jawaban), semua kelompok bergantian sampai semuanya dapat bermain sebagai kelompok pertanyaan, jawaban, dan penilai, siswa membuat kesimpulan dengan guru tentang materi yang telah disampaikan.

Kegiatan pembelajaran yang dilakukan adalah mengamati kegiatan yang dilakukan siswa selama pelaksanaan pemebelajaran dengan menggunakan metode Make A Match. Dengan cara mengisi lembar observasi aktivitas guru dan siswa saat pelaksanaan pembelajaran.

Kegiatan pembelajaran yang dilakukan adalah merefleksikan kegiatan yang telah dilakukan siswa selama pelaksanaan pembelajaran apakah siswa berperan secara aktif dalam pembelajaran, apakah proses pembelajaran tidak menjenuhkan, apakah hasil belajar siswa semakin meningkat dengan menggunakan metode pembelajaran Make A Match pada mata pelajaran Akidah Akhlak materi berperilaku terpuji. Hal ini dimaksudkan agar hasil refleksi ini dapat berguna bagi siswa maupun guru di masa yang akan datang.

Analisis Data

a. Jenis data

Jenis data yang digunakan dalam penelitian ini adalah aktivitas dalam pembelajaran dan hasil belajar akidah akhlak.

b. Sumber data

Sumber data diperoleh dari Siswa dan Guru.

c. Alat dan Teknik pengumpulan data

Analisis data pada penelitian ini yaitu menggunakan data tes dan non tes. Hasil pengolahan data kemudian akan menjadi hasil penelitian pada setiap siklusnya. Adapun pengolahan datanya sebagai berikut: 
1) Untuk mengetahui rumusan masalah nomor 1 tentang penggunaan metode make $a$ match dapat meningkatkan hasil belajar siswa pada mata pelajaran akidah akhlak pokok bahasan berperilaku terpuji, dapat dianalisis menggunakan data kuantitatif adalah sebagai berikut:

a) Menghitung ketuntasan belajar secara individual, dengan rumus:

$$
\begin{aligned}
& \frac{\text { Skor yang dicapai siswa }}{\text { Skor maksimal }} \times 100 \% \\
& \frac{\text { Skor yang dicapai guru }}{\text { Skor maksimal }} \times 100 \%
\end{aligned}
$$

b) Menghitung rata-rata nilai seluruh siswa, dengan rumus:

$$
\mathrm{X}=\frac{\sum x}{N}
$$

Keterangan:

$\mathrm{X}=$ Nilai rata-rata kelas

$\sum \mathrm{x}=$ Jumlah nilai seluruh siswa

$\mathrm{N}=$ Jumlah seluruh siswa

Soal yang digunakan pada pre test adalah soal yang berbentuk pilihan ganda yang diambil dari hasil tes uji coba soal yang telah diuji cobakan pada sebelumnya dan yang telah dianalisis.

c) Menghitung ketuntasan belajar secara, dengan rumus:

$$
\frac{\text { jumlah siswa tuntas belajar }}{\text { jumlah seluruh siswa }} \times 100 \%
$$

(Hayati, 2014, hlm. 152)

2) Untuk mengetahui rumusan masalah nomor 2 tentang bagaimana proses pembelajaran dengan menggunakan metode make a match dalam pembelajaran akidah akhlak pokok bahasan berperilaku terpuji yaitu data yang diperoleh dari hasil lembar observasi aktivitas guru dan siswa dianalisis menggunakan data deskriftif kualitatif dengan mendeskripsikan aktivitas yang dilakukan dalam proses pembelajaran setiap siklus.

$$
\mathrm{P}=\frac{\mathrm{f}}{N} \times 100 \%
$$

Keterangan :

$\mathrm{P}=$ Presentase aktivitas guru atau siswa

$\mathrm{F}=$ Banyaknya aktivitas guru atau siswa yang muncul

$\mathrm{N}=$ Jumlah aktivitas keseluruhan

(Sudijono, 2011, hlm. 43)

Kriteria

$$
\begin{array}{ll}
80 \%-100 \% & =\text { Sangat Baik } \\
66 \%-79 \% & =\text { Baik } \\
56 \%-65 \% & =\text { Cukup Baik } \\
40 \%-55 \% & =\text { Kurang Baik }
\end{array}
$$




\section{HASIL DAN DISKUSI}

Kemampuan akhir siswa merupakan kemampuan dalam memahami pembelajaran setelah disampaikan, dan materi pokok yang disampaikan pada penelitian ini adalah berperilaku terpuji. Kemampuan tersebut dapat diketahui melalui pemberian tes terakhir pada setiap siklus yang telah dilaksanakan.

Berdasarkan siklus yang telah dilaksanakan mulai dari siklus I dan siklus II, keterlibatan siswa dalam proses pembelajaran berlangsung dengan aktif. Baik secara klasikal maupun secara kelompok. Berdasarkan penelitian siklus I rata-rata nilai aktivitas siswa mencapai $75 \%$ dengan kategori baik, sedangkan pada siklus II mengalami peningkatan mencapai 92\% dengan kategori sangat baik. Selain aktivitas siswa, aktivitas guru juga mengalami peningkatan yang signifikan ke arah yang lebih baik dari siklus ke siklus. Hasil yang diperoleh pada siklus I mencapai $67 \%$ dengan kategori baik, sedangkan pada siklus II mencapai $89 \%$ dengan kategori sangat baik.

Setelah menggunkan metode pembelajaran make a match dapat dilihat peningkatan hasil belajar siswa. Sebelum menggunakan metode pembelajaran make a match, hasil belajar siswa yaitu dengan nilai rata-rata 54,2. Setelah menggunakan metode pembelajaran make a match pada siklus I, hasil belajar siswa meningkat dengan nilai rata-rata 68,67. Hasil belajar pada siklus II meningkat dengan nilai rata-rata 88 .

Tabel 1. Data Hasil Pre Test, Siklus I dan Siklus II

\begin{tabular}{|c|c|c|c|c|}
\hline No. & Nama Siswa & Pre Test & Siklus I & Siklus II \\
\hline 1. & $\mathrm{~A}$ & 34 & 50 & 70 \\
\hline 2. & $\mathrm{~B}$ & 54 & 80 & 90 \\
\hline 3. & A & 54 & 60 & 80 \\
\hline 4. & $\mathrm{~B}$ & 80 & 90 & 100 \\
\hline 5. & $\mathrm{C}$ & 34 & 60 & 90 \\
\hline 6. & $\mathrm{D}$ & 80 & 80 & 100 \\
\hline 7. & $\mathrm{E}$ & 40 & 70 & 90 \\
\hline 8. & $\mathrm{~F}$ & 74 & 80 & 100 \\
\hline 9. & $\mathrm{G}$ & 34 & 50 & 80 \\
\hline 10. & $\mathrm{H}$ & 80 & 80 & 100 \\
\hline 11. & $\mathrm{I}$ & 54 & 70 & 80 \\
\hline 12. & $\mathrm{~J}$ & 54 & 80 & 90 \\
\hline 13. & $\mathrm{~K}$ & 67 & 70 & 90 \\
\hline 14. & $\mathrm{~L}$ & 40 & 60 & 80 \\
\hline 15. & $\mathrm{M}$ & 34 & 50 & 80 \\
\hline \multicolumn{2}{|r|}{ Jumlah } & $\mathrm{N}$ & 1030 & 1320 \\
\hline \multicolumn{2}{|r|}{ Rata-Rata } & $\mathrm{O}$ & 68,67 & 88 \\
\hline \multicolumn{2}{|c|}{ Presentase Ketuntasan } & $26,67 \%$ & $66,67 \%$ & $100 \%$ \\
\hline
\end{tabular}

Tabel 1 di atas merupakan hasil rata-rata kemampuan belajar siswa pada pre test, siklus I dan siklus II, untuk mempermudah melihat peningkatan hasil belajar siswa dapat dilihat pada gambar grafik dibawah ini. 


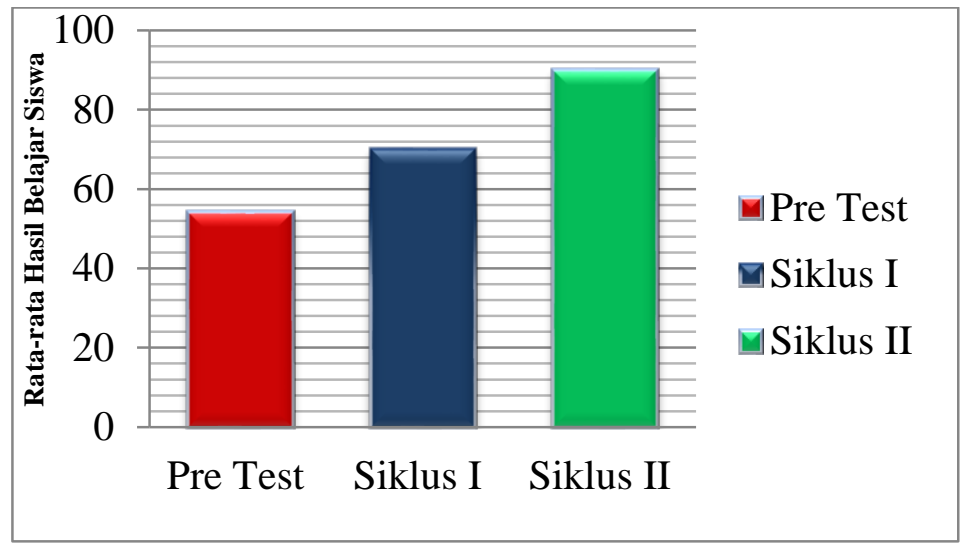

Grafik 1. Peningkatan Hasil Belajar Siswa mulai dari sebelum tindakan samapi setelah tindakan

Peningkatan aktivitas guru pada setiap siklus dapat dilihat pada tabel berikut:

Tabel 2 Presentase Aktivitas Guru Pada Setiap Siklus

\begin{tabular}{|c|c|c|c|c|}
\hline \multirow{2}{*}{ No. } & Pembelajaran & \multicolumn{2}{|c|}{ Skor Rata-rata (\%) } & \multirow{2}{*}{ Keterangan } \\
\cline { 3 - 4 } & & Terlaksana & Tidak terlaksana & \\
\hline 1. & Siklus I & $67 \%$ & $33 \%$ & Baik \\
\hline 2. & Siklus II & $89 \%$ & $11 \%$ & Sangat Baik \\
\hline
\end{tabular}

Adapun presentase aktivitas guru jika dilihat pada gambar 2.

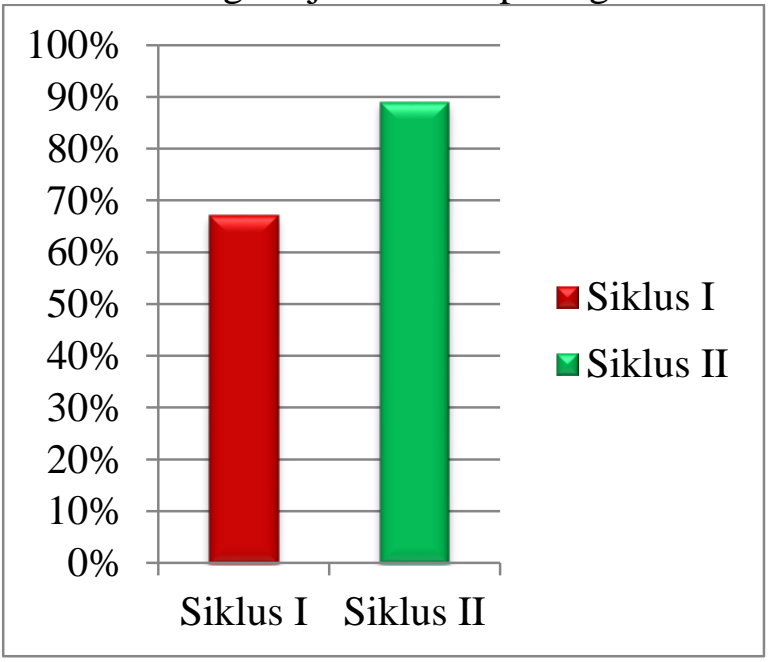

Grafik 2. Presentase Aktivitas Guru

Peningkatan aktivitas siswa pada setiap siklus dapat dilihat pada tabel berikut.

Tabel 3. Presentase Aktivitas Siswa Pada Setiap Siklus

\begin{tabular}{|c|c|c|c|c|}
\hline \multirow{2}{*}{ No. } & Pembelajaran & \multicolumn{2}{|c|}{ Skor Rata-rata (\%) } & \multirow{2}{*}{ Keterangan } \\
\cline { 3 - 4 } & & Terlaksana & Tidak terlaksana & \\
\hline 1. & Siklus I & $75 \%$ & $25 \%$ & Baik \\
\hline 2. & Siklus II & $92 \%$ & $8 \%$ & Sangat Baik \\
\hline
\end{tabular}


Adapun presentase aktivitas siswa jika dilihat pada gambar di bawah ini.

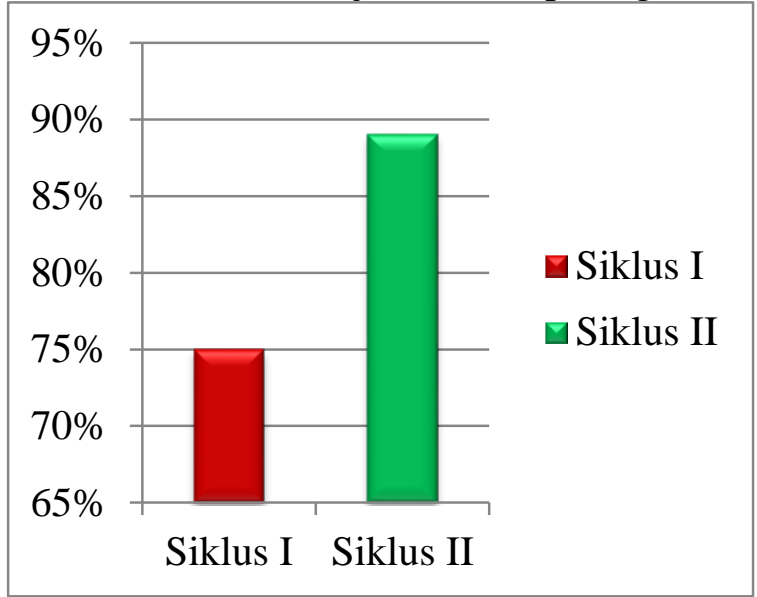

Grafik 3. Presentase Aktivitas Siswa

\section{KESIMPULAN}

Berdasarkan hasil yang diperoleh dari penelitian mengenai "Usaha Guru Meningkatkan Hasil Belajar Siswa Dengan Menggunakan Metode Pembelajaran Make A Match Pada Mata Pelajaran Akidah Akhlak Materi Berprilaku Terpuji" yang dilaksanakan di MIS Cikulu, dapat disimpulkan sebagai berikut.

1. Hasil belajar siswa kelas IV di MIS Cikulu, sebelum menggunakan metode pembelajaran make a match ditunjukan dengan nilai rata-rata 54,2 yang termasuk kualifikasi rendah, karena nilai rata-rata tersebut berada dibawah nilai KKM yang sudah ditentukan yaitu 70 .

2. Proses penggunaan metode pembelajaran make a match pada siklus I belum terlaksana dengan baik sebagaimana mestinya, maka diperbaiki pada siklus II. Pada siklus II penggunaan metode pembelajaran make a match sudah terlaksana dengan lebih baik sebagaimana mestinya sesuai dengan hasil refleksi pada siklus I. Berdasarkan hasil observasi aktivitas guru dalam proses pembelajaran yang mengalami peningkatan setiap siklusnya. Siklus I presentase aktivitas guru sebesar $67 \%$ dengan kategori baik, dan siklus II presentase aktivitas guru sebesar $89 \%$ dengan kategori sangat baik. Berdasarkan hasil observasi aktivitas siswa dalam proses pembelajaran yang mengalami peningkatan setiap siklusnya. Siklus I presentase aktivitas siswa sebesar $75 \%$ dengan kategori baik, dan siklus II presentase aktivitas siswa sebesar $92 \%$ dengan kategori sangat baik.

3. Hasil belajar siswa kelas IV MIS Cikulu, setelah menggunakan metode pembelajaran make a match, mengalami peningkatan hasil belajar secara signifikan. Pada siklus I, hasil belajar siswa ditunjukan dengan nilai rata-rata 68,67 yang termasuk kualifikasi sedang dan pada siklus II mencapai nilai rata-rata 88 yang termasuk kualifikasi tinggi.

\section{DAFTAR PUSTAKA}

Aqib. (2010). Penelitian Tindakan Kelas. Bandung: Yrama Widya.

Hayati, T. (2013). Evaluasi Pembelajaran. Bandung: Insan Mandiri.

Heriawan, A. dkk. (2012). Metodelogi Pembelajaran Kajian Teoretis Praktis. Serang Banten: LP3G.

Pidarta, M. (2007). Landasan Kependidikan. Jakarta: Rineka Cipta

Shoimin, A. (2014). 68 Model Pembelajaran Inovatif dan Kurikulum 2013. Yogyakarta: Ar-Ruzz Media 
Sudijono, A. (2011). Pengantar Statistik Pendidikan. Jakarta: PT Rajagrapindo.

Suprijono. (2014). Cooperative Learning Teori \& Aplikasi PAIKEM. Yogyakarta: Pustaka Pelajar. 